UDC 316.17

LBC 60.563 .05

\title{
INTERNET MEDIATIZATION OF CONFESSION IN THE ORTHODOX SOCIAL NETWORKING SIGHT VK.COM ${ }^{1}$
}

\author{
Elena A. Ostrovskaya \\ Saint Petersburg State University, Saint Petersburg, Russian Federation
}

\begin{abstract}
The mediatization of social reality, which confidently declared itself in the early 2000 s, is clearly presented as a new digital dimension of religion. Religions of the historical heritage of Russia actively master modern media and digital space of the Internet, create their own media environment of religious network interactions and events, discourses concerning society. The mediatizationof religions has the effect of changing the communicative profile of religions, promoting their topics in a broad public discussion on a par with the political and economic agenda. Modern sociological analysis of religion as an integral part of society now involves the search for answers to the question about the correlation of offline measurements of religious interactions, organizations and communications with their online presentations. One of the actual directions of sociological research of the digital space of religious interaction and discourses was the concept of mediatization of religion, developed by the joint efforts of scientists of the international team "Scandinavian research network". In line with this concept, the author refers to the study of the communicative aspect of the confession of the Orthodox faithful in its offline-online dimensions. As a basic and minimal unit of religious participation, confession as an interaction presents aspects of affiliation, religious-worldview and activity involvement. Central to the consideration in this article is the problem of studying the formats of confession representation in a variety of communicative themes of the digital environment of Orthodox parishes. The study in its full volume was carried out in several stages in $2017-$ 2018 years. For two years the author has been conducting an offline structured observation of confession in the Orthodox churches of Ekaterinburg, processing and analysis of the results; consequently we carried out operationalization of observation units in relation to online communication confession, collected, processed and analyzedthe data. In 2018, the author undertook a study of media communication network vk.com communities of Ekaterinburg parishes, applying structured observation and qualitative content analysis. Using a continuous, multistage, quota sampling, the author has explored digital landscapes, and key communication subjects digital communication $22 \mathrm{vk}$.com communities of the parishes of Ekaterinburg. The results of our study are presented in detail and analyzed in the article.
\end{abstract}

Key words: mediatization of religion, Internet communication, Orthodox social networking site vk.com, confession as a digital communication, complete structured observation, content analysis, units of structured observation.

УДК 316.17

ББК 60.563 .05

\section{ИНТЕРНЕТ-МЕДИАТИЗАЦИЯ ИСПОВЕДИ В СРЕДЕ ПРАВОСЛАВНЫХ СЕТЕВЫХ VК.СОМ СООБЩЕСТВ ${ }^{1}$}

\section{Елена Александровна Островская}

Санкт-Петербургский государственный университет, г. Санкт-Петербург, Российская Федерация

Аннотация. Медиатизация социальной реальности, уверенно заявившая о себе в начале 2000-х гг., со всей отчетливостью предстает и как новое цифровое измерение религии. Религии исторического наследия России активно осваивают современные медиа и цифровое пространство интернета, создают собственную медиасреду религиозных сетевых взаимодействий и событий, дискурсов об обществе. Медиатизация религий имеет своим следствием изменения коммуникативного профиля религий, продвижения их тем в 
широкое общественное обсуждение наравне с политической и экономической повесткой. Современный социологический анализ религии как неотьемлемой составляющей социума предполагает теперь поиск ответов на вопрос о соотнесенности офлайн-измерений религиозных взаимодействий, организаций и коммуникаций с их онлайн-презентациями. Одним из актуальных направлений социологических исследований цифрового пространства религиозного взаимодействия и дискурсов стала концепция медиатизации религии, разработанная совместными усилиями ученых международного коллектива «Скандинавская исследовательская сеть». В русле этой концепции автор статьи обращается к исследованию коммуникативного аспекта исповеди православных верующих в ее офлайн- / онлайн-измерениях. В качестве базовой и минимальной единицы религиозного участия исповедь как взаимодействие презентирует аспекты аффилиации, религиозно-мировоззренческой и деятельностной вовлеченности. Центральной для рассмотрения в настоящей статье является проблема изучения форматов представленности исповеди в разнообразии коммуникативных тем цифровой среды православных приходов. Исследование в полном своем объеме проводилось в несколько этапов в 2017-2018 годах. В течение двух лет было проведено офлайн-структурированное наблюдение исповеди в православных храмах Екатеринбурга, обработка и анализ полученных результатов; операционализация единиц наблюдения применительно к онлайн-коммуникации исповедь, сбор, обработка и анализ данных. В 2018 г. автором было предпринято исследование медиакоммуникации сетевых vk.com сообществ приходов Екатеринбурга с применением структурированного наблюдения и качественного контент-анализа. При осуществлении сплошной, многоступенчатой, квотной выборки исследователем были изучены цифровые ландшафты и ключевые коммуникативные тематики цифрового взаимодействия $22 \mathrm{vk.com} \mathrm{сообществ} \mathrm{приходов} \mathrm{Екатеринбурга.} \mathrm{Результаты} \mathrm{этого} \mathrm{исследования} \mathrm{подробно} \mathrm{пред-}$ ставлены и проанализированы в настоящей статье.

Ключевые слова: медиатизация религии, интернет-коммуникация, православные сетевые vk.com coобщества, исповедь как цифровая коммуникация, сплошное структурированное наблюдение, контент-анализ, единицы структурированного наблюдения.

Социологические исследования последних двух десятилетий все чаще сталкиваются с необходимостью учитывать изменившиеся параметры реальности общества XXI в., являющего себя как реальность в ее непосредственной данности и в многообразии нового медийного интернет-измерения. Современное изучение общества требует от исследователя включать в дизайн своих прикладных проектов такой аспект, как изучение объекта в его медийном интернет-формате. Следует подчеркнуть, что отечественная социология активно вторгается в изучение интернета как новой медийной социальной среды и коммуникации с присущими ей сценариями, контекстами взаимодействий, открытыми и закрытыми сообществами, правилами включения и исключения, социальными аренами и дискурсами [1]. Таким образом, специфика социологических исследований, обозначаемых как «социология 2.0», состоит не только в обновлении методологии и методического инструментария исследований, но в комплексности охвата объекта. В этом же направлении весьма активно продвигается и социология религии, одна из первых столкнувшаяся с цифровой средой религиозных текстов, сетевых сообществ и организаций, с феноменом медиатизации религии как коммуникации, трансформирующей привычные религиозные институты и дискурсы. И здесь мы имеем в виду в первую очередь оцифрование канонических и постканонических религиозных текстов, инициированное католической церковью в 1950-х гг. еще на заре компьютеризации социальной среды, подхваченное в дальнейшем представителями различных христианских конфессий и вошедшее в широкую практику различных религиозных организаций в 1990-х гг. [4, p. 4-5]. Отметим, что цифровая социология религии начала свое развитие именно как дисциплина, организующая свое собственное медиапространство в интернете в форме открытых и закрытых блогов профессиональных исследователей религии, сайтов, посвященных сбору данных по исследованиям конкретных религиозных традиций или тем, и пр. Офлайн-социология религии делает свои первые шаги в начале 1990-х гг., адресуя исследовательские вопросы в направлении изучения проблемы параметров изменения религиозного опыта, религиозных идентичностей и практик под влиянием новых компьютерных технологий и киберпространства современной культуры [3, p. 1083-1084].

Разворот социологического дискурса о медиатизации религии осуществился только 
в начале 2000-х гг. социологами, антропологами, теологами из Дании, Швеции, Норвегии, Финляндии, объединившими свои усилия в рамках международного проекта «Скандинавская исследовательская сеть по изучению медиатизации религии и культуры» (The Nordic Research Network on the Mediatisation of Religion and Culture (MRC). В числе ее участников оказались Хайди Кэмпбелл, Миа Левхайм, Стиг Хьявард, работы которых задали принципиально новый ракурс рассмотрения проблемы цифрового измерения религии. Так, авторству Хьяварда принадлежит концепция медиатизации религии, описывающая в языке социологии феномен влияния медиасреды на религиозные практики, идентичности и дискурсы, подвергающей их преобразованию и вместе с тем впитывающей в свою очередь религиозные смыслы и коммуникации. Он предложил обозначить этот двунаправленный процесс влияния медиасреды на религию и наоборот понятием «медиатизация религии», что означает многомерные трансформации религии, выражающиеся в изменении религиозных текстов, практик и отношений, характера самой веры в современном обществе [9, p. 24-27]. Обозначить отчетливые контуры результатов этого сложного процесса вероятно окажется возможным в ситуации многомерных и кросскультурных исследований цифрового измерения различных религиозных традиций и инноваций в интернет и медиасреде и наоборот.

Предлагаемое в настоящей статье рассмотрение результатов исследования коммуникативных компонентов исповеди в интернетсреде православных храмов мыслилось именно в русле перспективы, заданной скандинавской исследовательской группой. Одним из центральных стал вопрос о корреляции офлайнрелигиозных коммуникаций в среде православных верующих их онлайн-коммуникациям в формате vk.com сообществ. Исповедь как взаимодействие трактуется нами в качестве базовой и минимальной единицы участия, позволяющей изучать и аспект аффилиации, и аспекты религиозно-мировоззренческие, и деятельность вовлеченности верующих. Исследование в полном своем объеме проводилось в несколько этапов: офлайн-структурированное наблюдение исповеди в православных хра- мах Екатеринбурга, обработка и анализ полученных результатов; операционализация единиц наблюдения применительно к онлайн-коммуникации исповедь, сбор, обработка и анализ данных. В его офлайн-части в фокусе внимания наряду с полевой частью оказалась экспликация методологии структурированного наблюдения в формате «сплошное / толстое описание» и самих единиц наблюдения, выложенных по протоколам [2, с. 71-115]. Следующим шагом стало применение структурированного наблюдения компонентов исповеди как взаимодействия в их коммуникативном интернет-формате.

Скажем несколько слов о критериях спецификации объекта. В этой части проектного исследования мы сосредоточились на анализе онлайн-коммуникации «исповедь» в том виде, в котором она предстает в цифровой реальности екатеринбургских приходов. В фокус изучения были взяты сетевые сообщества популярной российской медиасреды vk.com. Такая спецификация объекта представлялась нам интересной прежде всего потому, что социальная сеть vk.com является специфически российским цифровым пространством интернета, активно используемым религиями исторического наследия России. В контексте рассмотрения всей полноты объекта в его офлайн- / онлайн-вариациях - религиозного взаимодействия по типу исповедь - эта социальная сеть единственная предоставляет возможность выявления коммуникативной тематизации офлайн-взаимодействий в цифровой среде. Здесь необходимо отметить, что из всего многообразия социальных сетей и интернет-ресурсов екатеринбургские приходы используют преимущественно социальную сеть vk.com. Кроме того, они могут иметь собственные сайты, некоторые из них создали каналы на платформе YouTube. В социальных сетях Odnoklassniki, Telegram, Instagram екатеринбургские храмы не обнаруживаются. Кроме того, их самопрезентация на собственных сайтах и на платформе YouTube не является интерактивной и позволяет наблюдать единицы исповеди только в аспекте информации о них. Изучение тематизированности исповеди в контексте взаимодействия сетевых храмовых сообществ в vk.com позволяет установить, какие структурные единицы исповеди в 
принципе востребованы в цифровом взаимодействии и каков содержательный объем коммуникации по теме исповедь.

Сплошное структурированное наблюдение коммуникативных единиц исповеди в контексте взаимодействия сетевых vk.com сообществ православных приходов Екатеринбурга проводилось в период с марта по июль 2018 года. В ходе зондажного обследования медиапространства екатеринбургских храмов выяснилось, что из изученных ранее в ходе полевого наблюдения 34 православных приходов собственными площадками в цифровом пространстве российской социальной сети vk.com располагает только 21 храм. В целях сопоставимости результатов полевого наблюдения исповеди как взаимодействия и наблюдения ее единиц в качестве коммуникации в медиасреде социальной сети vk.com были использованы параметры первоначальной выборки, которая выстраивалась как сплошная, многоступенчатая и квотная. Таким образом в выборку вошли сайты и сетевые vk.com coобщества, представительствующие в выборке квоты храмов центра города, спальных и окраинных районов. Контент-анализ сетевых vk.com сообществ показал, что один из храмов имеет 2 группы в указанной социальной сети. Используя схему, разработанную ранее для презентации квотной выборки полевого наблюдения исповеди как взаимодействия, мы представили анализ полученных данных в сводных таблицах, репрезентирующих все единицы цифрового измерения исповеди в интернет-среде 22 храмовых сетевых vk.com сообществ, отобранных для рассмотрения (см. табл. 1-3).

Ключевыми методами сбора и анализа данных на этапе изучения исповеди в медиасреде храмов Екатеринбурга явились сплошное структурированное наблюдение и качественный контент-анализ. Здесь необходимо сказать подробнее о каждом из методов применительно к объекту исследования.

Сплошное структурированное наблюдение представленности в интернет-коммуникации компонентов исповеди проводилось с использованием комбинации стратегии thick description в версии Н. Дензина [8; 7] и структурированного наблюдения в разработанной ранее операционализации. Метод сплошного наблюдения в версии Н. Дензина был выбран как позволяющий отследить не только все структурные единицы объекта исследования, но и коммуникативный контекст. Согласно Н. Дензину сама техника сплошного описания предполагает отслеживание всех компонентов взаимодействия - акторов - их цель и средства для ее достижения, пространственно-временную спецификацию взаимодействия, его темы и контекст [5, р. 930; 8, p. 55]. Применительно к исследованию медийной среды жизнедеятельности приходов это означает, что необходимо принимать во внимание весь объем коммуникативного контекста, в котором существует интересующий исследователя объект. В предпринятом нами изучении коммуникативного аспекта исповеди в цифровом пространстве социальной сети vk.com фокус внимания был сосредоточен не только на каждой из единиц исповеди как взаимодействия, но и на конкретном коммуникативном контексте, в котором каждая из них обнаруживается.

Отметим, что в нашем исследовании речь шла не о наблюдении видеотрансляций или прямого тематизированного взаимодействия по типу исповедь (как это ранее делалось на этапе офлайн-полевого наблюдения). В рамках этой части исследования объектом наблюдения выступили коммуникативные единицы исповеди в цифровом взаимодействии сетевых храмовых vk.com сообществ. В фокус внимания был поставлен смысловой компонент исповеди. Одним из центральных стал вопрос о том, каким образом исповедь как коммуникация (смысловой аспект взаимодействия) представлена в цифровом измерении жизни екатеринбургских приходов? В силу этого каждая из единиц наблюдения была операционализирована таким образом, чтобы выявить ее тематизацию в контексте взаимодействия сетевых сообществ приходов.

Отдельной методологической проблемой, выявившейся в ходе использования метода сплошного структурированного наблюдения к изучению сетевого пространства храмов, стала операционализация структурных единиц полевого наблюдения для рассмотрения онлайн-коммуникации vk.com сообществ. В качестве единиц полевого наблюдения вы- 
ступали следующие: священник, прихожане, пространство храма, где проходит исповедь, время проведения исповеди, исповедь как тема и контекст, обнаруживаемый в ходе полевого наблюдения и слагающийся из ситуативной конкретики данных по каждой из единиц. Применительно к онлайн-наблюдению коммуникативных компонентов исповеди были сохранены единицы «священник» и «прихожане», но теперь надлежало отследить описания / обсуждения ценностно-нормативных аспектов их деятельности как акторов взаимодействия по типу исповедь. Заново пришлось операционализировать структурную единицу «пространство храма» - в медийном измерении она представлена «интернет-пространством конкретных приходов» - собственные сайты, профили в социальных сетях, группы в социальной сети vk.com, каналы на платформе YouTube. Коммуникативный аспект единицы «время» был операционализирован как интернет-расписание недельных служб. Смысловая составляющая единицы «цель и средства» - это исповедь как ритуал или совокупность обсуждений, проповедей, лекций и т. п., раскрывающих смысл действий, нормативных и обязательных для данного ритуального взаимодействия. Структурная единица «тема» в цифровом пространстве обозначена коммуникативным аспектом исповеди как таинства. И, наконец, единица «контекст», как и в случае непосредственного наблюдения, - это комбинация перечисленных единиц в контексте онлайн-взаимодействия конкретных сетевых vk.com сообществ соответствующих приходов.

Метод качественного контент-анализа позволил выявить тематическое разнообразие коммуникаций онлайн-взаимодействий внутри храмовых vk.com сообществ, трактуемых в качестве медийной среды избранного для изучения объекта. Кроме того, с помощью контент-анализа предполагалось установить востребованность коммуникации исповедь среди других тематизированных взаимодействий прихожан и священников сетевых сообществ храмов. В этой связи контент-анализ был использован преимущественно для изучения исповеди как коммуникации в контексте изучения интерактивных стен, рубрик и тематик взаимодействия храмовых групп в vk.com.
Итак, из 24 обследованных храмов собственными группами в социальной сети vk.com располагают 22. Среднее число подписчиков сетевых сообществ vk.com екатеринбургских храмов - 486 человек. Коммуникативное содержание взаимодействия в этих группах структурировано с помощью 11 рубрик, которые являются стандартными для этой социальной сети: «информация», «новости», «участники», «ссылки», «фото», «видео», «мероприятия», «контакты», «аудио», «обсуждения», «документы». Вместе с тем подборка рубрик из этого стандартного набора создается администраторами групп. Анализ этих подборок позволяет утверждать, что в 21 случае из 22 самыми востребованными в сетевом взаимодействии прихожан оказываются следующие: «информация», «контакты», «участники», «фото», «видео», «ссылки». Со средней частотностью встречаются рубрики: «новости», «документы», «аудиозаписи» - 8 случаев из 22. Такие коммуникативно весомые рубрики, как «мероприятия» и «обсуждения», находятся в числе слабо информативных и редко используемых - 5 случаев из 22.

Наше рассмотрение данных, полученных в ходе структурированного наблюдения и контент-анализа коммуникативных компонентов исповеди в цифровой среде храмовых vk.com сообществ, мы выстраивали по единой схеме, предполагающей объединение групп по квотам - храмы центра, спальных районов и окраины; контент-анализ распространенности рубрик и коммуникативных тем цифровой среды сообществ; выявление частотности появления структурных единиц исповеди в коммуникативном контексте каждого храмового vk.com сообщества. Таким образом, наш последующий анализ выстраивается именно в соответствии с предложенной схемой.

\section{Храмы центра - 11 vk.com сообществ}

(см. табл. 1)

В цифровом коммуникативном пространстве vk.com Свято-Троицкий Кафедральный собор представлен группой прихрамового молодежного клуба «Рассвет». Ее содержание структурировано стандартным 
сетевым набором рубрик: «информация», «участники», «ссылки», «фотоальбомы», «видеозаписи», «аудиозаписи», «голосование», «мероприятия», «контакты», причем каждая из них активна и заполнена актуальным материалом. Самыми подвижными в аспекте взаимодействия являются интерактивная стена и рубрики «фотоальбомы» и «обсуждения». Как показал контент-анализ, наиболее актуальными являются две темы: анонсы и фотоотчеты о встречах членов клуба в храме и об их внехрамовой совместной деятельности; встречи, проводимые Екатеринбургской епархией для православной молодежи в других приходах города (паломнические поездки, принесение мощей, молебны, службы и публичные встречи с Патриархом Московским и Всея Руси Кириллом в Екатеринбурге). В группе 9 «обсуждений», наиболее частотны здесь темы проведения праздников в храме и участие в паломнических поездках.

Таблица 1

Храмы центральных районов

\begin{tabular}{|c|c|c|c|c|c|c|c|}
\hline П.н. & Храм & Священник & Прихожане & $\begin{array}{l}\text { Группы } \\
\text { в vk.com }\end{array}$ & $\begin{array}{l}\text { Исповедь } \\
\text { в расписа- } \\
\text { нии служб } \\
\end{array}$ & Исповедь как ритуал & $\begin{array}{c}\text { Исповедь } \\
\text { как таинство }\end{array}$ \\
\hline 1 & $\begin{array}{l}\text { Свято-Троицкий } \\
\text { кафедральный } \\
\text { собор }\end{array}$ & Нет & Нет & $\begin{array}{l}\text { https://vk.com/ } \\
\text { club25347261 }\end{array}$ & $\begin{array}{l}\text { Нет распи- } \\
\text { сания }\end{array}$ & Нет & Нет \\
\hline 2 & $\begin{array}{l}\text { Всех святых, в } \\
\text { земле Россий- } \\
\text { ской просияв- } \\
\text { ших (Храм- } \\
\text { Памятник на } \\
\text { Крови) }\end{array}$ & Нет & Нет & $\begin{array}{l}\text { https://vk.com/t } \\
\text { emple_of_the_ } \\
\text { blood }\end{array}$ & $\begin{array}{l}\text { Нет распи- } \\
\text { сания }\end{array}$ & $\begin{array}{l}\text { На интерактивной сте- } \\
\text { не один пост о связи } \\
\text { исповеди и причастия. } \\
\text { Это цитата из речи пат- } \\
\text { риарха Кирилла о } \\
\text { взаимосвязи причастия } \\
\text { и исповеди (пост от от } \\
15.04 .2018 \text { г.). В проци- } \\
\text { тированном фрагменте } \\
\text { говорится о необходи- } \\
\text { мости частого прича- } \\
\text { щения, условием кото- } \\
\text { рого является исповедь }\end{array}$ & Нет \\
\hline 3 & $\begin{array}{l}\text { Вознесения Гос- } \\
\text { подня }\end{array}$ & Нет & Нет & $\begin{array}{l}\text { https://vk.com/v } \\
\text { oznesenka_ekb }\end{array}$ & $\begin{array}{l}\text { Нет распи- } \\
\text { сания }\end{array}$ & Нет & Нет \\
\hline 4 & $\begin{array}{l}\text { Православный } \\
\text { Приход Святи- } \\
\text { теля Николая } \\
\text { Чудотворца }\end{array}$ & Нет & Нет & $\begin{array}{l}\text { https://vk.com/ } \\
\text { nikolahram }\end{array}$ & $\begin{array}{l}\text { Имеется } \\
\text { рубрика } \\
\text { «расписание } \\
\text { богослуже- } \\
\text { ний»; время } \\
\text { исповеди в } \\
\text { ней не обо- } \\
\text { значено } \\
\end{array}$ & Нет & Нет \\
\hline 5 & $\begin{array}{l}\text { Всех Святых на } \\
\text { Михайловском } \\
\text { кладбище }\end{array}$ & Нет & Нет & $\begin{array}{l}\text { https://vk.com/ } \\
\text { hram_vs_ekb }\end{array}$ & $\begin{array}{l}\text { Имеется } \\
\text { рубрика } \\
\text { «расписание } \\
\text { богослуже- } \\
\text { ний», время } \\
\text { исповеди } \\
\text { ежедневно в } \\
16: 30 \\
\end{array}$ & Нет & Нет \\
\hline 6 & $\begin{array}{l}\text { Часовня святой } \\
\text { великомученицы } \\
\text { Екатерины }\end{array}$ & Нет & $\begin{array}{l}\text { Альбом } \\
\text { «приход в } \\
\text { лицах», в } \\
\text { котором фо- } \\
\text { тографии } \\
\text { прихожан с } \\
\text { подписан- } \\
\text { ными к ним } \\
\text { именами }\end{array}$ & $\begin{array}{l}\text { https://vk.com/ } \\
\text { ekbsobor }\end{array}$ & $\begin{array}{l}\text { Имеется } \\
\text { рубрика } \\
\text { «расписание } \\
\text { богослуже- } \\
\text { ний», время } \\
\text { исповеди: } \\
\text { еженедельно } \\
\text { по субботам } \\
\text { в 18:00; по } \\
\text { воскресень- } \\
\text { ям в 09:00 }\end{array}$ & $\begin{array}{l}\text { На интерактивной сте- } \\
\text { не отчет о беседе со } \\
\text { священником, посвя- } \\
\text { щенной исповеди; там } \\
\text { же рассуждения быв- } \\
\text { шего православного } \\
\text { пастора (ныне право- } \\
\text { славный священник) о } \\
\text { важности исповеди }\end{array}$ & \\
\hline
\end{tabular}


E.A. Островская. Интернет-медиатизация исповеди в среде православных сетевых vk.com сообществ

Окончание таблицы 1

\begin{tabular}{|c|c|c|c|c|c|c|c|}
\hline П.н. & Храм & Священник & Прихожане & $\begin{array}{c}\text { Группы } \\
\text { в vk.com }\end{array}$ & $\begin{array}{l}\text { Исповедь } \\
\text { в расписа- } \\
\text { нии служб }\end{array}$ & Исповедь как ритуал & $\begin{array}{c}\text { Исповедь } \\
\text { как таинство }\end{array}$ \\
\hline 7 & $\begin{array}{l}\text { В честь иконы } \\
\text { Божией Матери } \\
\text { «Порт- } \\
\text { Артурская» }\end{array}$ & $\begin{array}{l}\text { В сообщест- } \\
\text { ве vk. виде-- } \\
\text { запись пере- } \\
\text { дачи ТК } \\
\text { «Союз» } \\
\text { «Вторая по- } \\
\text { ловина» о } \\
\text { матушке } \\
\text { прихода }\end{array}$ & Нет & $\begin{array}{l}\text { https://vk.com/ } \\
\text { portarturural }\end{array}$ & $\begin{array}{l}\text { Нет распи- } \\
\text { сания }\end{array}$ & Нет & $\begin{array}{l}\text { На инте- } \\
\text { рактивной } \\
\text { стене посты } \\
\text { о важности } \\
\text { участия в } \\
\text { церковных } \\
\text { таинствах; } \\
\text { об их ду- } \\
\text { ховном } \\
\text { смысле; о } \\
\text { подготовке } \\
\text { к ним }\end{array}$ \\
\hline 8 & $\begin{array}{l}\text { Иоанно- } \\
\text { Предтеченский } \\
\text { собор }\end{array}$ & & Нет & $\begin{array}{l}\text { https://vk.com/i } \\
\text { vanovka_ekb }\end{array}$ & $\begin{array}{l}\text { Нет распи- } \\
\text { сания }\end{array}$ & $\begin{array}{l}\text { Основные темы встреч } \\
\text { прихрамового моло- } \\
\text { дёжного клуба, анон- } \\
\text { сированные в }\end{array}$ & Нет \\
\hline & & & & & & $\begin{array}{l}\text { сообществе vk.com-- } \\
\text { исповедь, покаяние, } \\
\text { причастие, забота о } \\
\text { ближнем }\end{array}$ & \\
\hline 9 & $\begin{array}{l}\text { Казанской ико- } \\
\text { ны Божией Ма- } \\
\text { тери, (Площадь } \\
\text { центрального } \\
\text { рынка 6) }\end{array}$ & Нет & Нет & $\begin{array}{l}\text { https://vk.com/ } \\
\text { hramkazansky_ } \\
\text { ekb }\end{array}$ & $\begin{array}{l}\text { Нет распи- } \\
\text { сания }\end{array}$ & Нет & Нет \\
\hline 10 & $\begin{array}{l}\text { Во имя Святите- } \\
\text { ля Иннокентия, } \\
\text { митрополита } \\
\text { Московского }\end{array}$ & Нет & Нет & $\begin{array}{l}\text { https://vk.com/ } \\
\text { st.innocentiy }\end{array}$ & $\begin{array}{l}\text { Нет распи- } \\
\text { сания }\end{array}$ & Нет & Нет \\
\hline 11 & $\begin{array}{l}\text { Православный } \\
\text { приход церкви } \\
\text { «Большой Зла- } \\
\text { тоуст» }\end{array}$ & Нет & Нет & $\begin{array}{l}\text { https://vk.com/ } \\
\text { club63682021 }\end{array}$ & $\begin{array}{l}\text { Имеется } \\
\text { рубрика } \\
\text { «расписа- } \\
\text { ние бого- } \\
\text { служений», } \\
\text { время испо- } \\
\text { веди не ука- } \\
\text { зано }\end{array}$ & $\begin{array}{l}\text { В рубрике «обсужде- } \\
\text { ния» есть тема «вопро- } \\
\text { сы батюшке», которая } \\
\text { содержит вопросы по } \\
\text { исповеди с ответами } \\
\text { священника }\end{array}$ & Нет \\
\hline
\end{tabular}

Центральный храм Екатеринбурга Всех святых, в земле Российской просиявших (Храм-Памятник на Крови) - также имеет собственное сетевое сообщество в vk.com. Взаимодействие здесь структурировано рубриками: «информация», «участники», «ссылки», «фото», «видео», «мероприятия», «контакты». Контент-анализ содержания постов и материалов группы показал, что самыми распространенными являются темы проведения в Екатеринбурге ежегодного фестиваля православной культуры «Царские дни», посвященного памяти семьи Императора Николя II; биографии членов императорской семьи; проведение служб, молебнов и открытых встреч Патриархом Московским и Всея Руси Кириллом; проведение служб Митрополитом Екатеринбургским и Верхотурским Кириллом.
Такая коммуникативная заостренность на теме «Царские дни» обусловлена историей возникновения самого храма, изначально построенного на месте расстрела царской семьи. Необходимо подчеркнуть, что Храм на Крови является главным православным храмом города, в силу чего он проводит на своей территории крупные мероприятия, относящиеся к православной жизни Екатеринбурга.

Взаимодействие сетевого сообщества vk.com Храма Вознесения Господня структурировано рубриками: «участники», «ссылки», «фотоальбомы», «видеозаписи», «контакты». Наибольшая коммуникативная активность выявлена на стене сообщества. В число наиболее актуальных тем стены и рубрик вошли пять: прибытие в город святых мощей; паломнические поездки; службы Патриарха 
Московского и Всея Руси Кирилла; курсы орнаментального шитья; деятельность отряда православных следопытов. Реже встречаются темы коммуникативной активности самого прихода, их две - социальная и благотворительная работы. В разделе «ссылки» обнаружены четыре линка на страницы, посвященные социальным проектам прихода.

Группа сетевого сообщества vk.com православный Приход Святителя Николая Чудотворца (Никольского храма при УГГУ) имеет рубрики: «участники», «ссылки», «фото», «видео», «аудио». Наиболее актуальными здесь являются четыре темы: жизнь прихода (паломнические поездки и молебны); деятельность приходской службы милосердия-сестричества во имя святой страстотерпицы царицы Александры; проведение фестиваля-семинара «Международный слет трезвости и здоровья», ежегодно проводимого приходом совместно с Екатеринбургской Епархией; деятельность кафедры теологии Уральского Государственного Горного Университета, к которому приписан храм; расписание богослужений. В фотоальбомах группы - снимки со встреч, лекций, бесед и праздничных служб прихода. В видеозаписях беседы с настоятелем храма о профилактике алкогольной и табачной зависимостей и видеозаписи с мест проведения благотворительных акций храма.

Сетевое взаимодействие группы vk.com Храма Всех Святых на Михайловском кладбище структурировано рубриками: «информация», «участники», «ссылки», «контакты». Рубрик «материалы», «фото» и «видео» на сайте нет. Наполнение имеющихся рубрик очень скудное. Контент-анализ стены и рубрик показал, что чаще всего обсуждаются две темы: расписание богослужений в храме (12 постов стены из имеющихся 27); жизнь прихода (паломнические поездки, ярмарки, встречи прихожан на службах и лекциях в храме). При Храме во имя всех святых на Михайловском кладбище существует церковноприходская школа, располагающая собственным сетевым сообществом в vk.com, - «Юбилейные встречи выпускников Церковной Приходской Школы». Наиболее востребованные темы здесь две - место и время проведения встречи; цитаты святоотеческой литературы.
Сетевое сообщество vk.com Храма Часовни Святой Великомученицы Екатерины структурировано рубриками «информация», «расписание богослужений», «участники», «ссылки», «фотоальбомы», «видеозаписи», «аудиозаписи», «документы», «обсуждения», «контакты». Контент-анализ тем интерактивной стены и рубрик показал, что превалируют четыре темы: анонсы грядущих событий и мероприятий Екатеринбургской Епархии (паломнические поездки, благотворительные акции, молебны); встречи английского клуба христианского общения, мероприятия прихрамового «Киноклуба»; разъяснения о порядке служб, о правилах чтения псалмов; жизнь прихода (паломнические поездки, праздники, торжественные службы). В рубриках «видеозаписи», «документы» и «обсуждения» чаще всего встречаются пять тем: проповеди священнослужителей храма; «Беседы с Батюшкой» православного телеканала «Союз» с участием настоятеля прихода; подведение итогов собраний, обсуждение деталей поездок, расписание служб, история собора.

Сетевое сообщество Храма в честь иконы Божией Матери «Порт-Артурская» структурировано следующими рубриками: «информация», «новости», «участники», «обсуждения», «фото», «видео» «контакты». Контент-анализ тем интерактивной стены и рубрик показал, что наиболее актуальны три темы: торжественные службы; цитаты святоотеческой литературы; деятельность воскресной школы.

Коммуникативное содержание взаимодействия сетевого сообщества vk.com группы Иоанно-Предтеченского собора структурировано рубриками: «участники», «ссылки», «фото», «видео», «мероприятия», «аудиозаписи», «контакты». Все без исключения разделы имеют наполнение. Контент-анализ выявил в качестве наиболее востребованных четыре темы: торжественные службы и молебны в храме, проводимые Митрополитом Екатеринбургским и Верхотурским Кириллом; встречи молодежного клуба; благоустройство храма и рутинная жизнь прихода.

Сетевое сообщество Храма Казанской иконы Божьей Матери (Площадь центрального рынка 6) коммуникативно представлено рубриками: «информация», «участники», 
«фото», «видео», «аудио», «обсуждения», «мероприятия», «контакты». Коммуникативно активны интерактивная стена и рубрики «фото», «видео», «аудио», «ссылки». Наиболее актуальны восемь тем: приезд и пребывание в городе святых мощей; благотворительные и образовательные мероприятия Екатеринбургской Епархии; прием абитуриентов в духовную семинарию Екатеринбурга; деятельность детской воскресной школы; «Беседы с батюшкой»; документальные фильмы о житиях святых и духовная музыка; ссылки на детские образовательные ресурсы православной тематики (жития святых, мультфильмы, сказки); толкования Библии и сборники православных текстов.

Сетевое сообщество храма во имя Святителя Иннокентия, Митрополита Московского структурировано рубриками: «информация», «новости», «обсуждения», «участники», «фото», «видео», «документы», «аудиозаписи», «контакты». Наиболее динамичны и разнообразны по темам и содержанию рубрики «фото», «видео», «аудио», «документы», «обсуждения». Контент-анализ тем интерактивной стены и рубрик показал, что чаще всего обсуждаются четыре темы: жизнь прихода; анонсы православной жизни города; обсуждения репортажей о беби-боксах (первый из которых был открыт именно при этом храме); «антисектантские» статьи, видео- и аудиозаписи бесед со священниками, предостерегающих прихожан против сект.

Сетевое сообщество храма православный приход церкви «Болышой Златоуст» структурировано рубриками: «информация», «новости», «участники», «ссылки», «фото», «видео», «аудио», «документы», «обсуждения», «контакты». Несмотря на разнообразие, их контент скуден. Контент-анализ тем интерактивной стены показал, что чаще всего встречаются пять из них: сбор средств на роспись храма; записи проповедей священника; деятельность службы милосердия храма, расписание богослужений, работа детской воскресной школы.

\section{Храмы спальных районов - 8 vk.com сообществ (см. табл. 2)}

Сетевое сообщество Градо-Екатеринбургская Симеоновская церковь-школа содержит рубрики: «информация», «новости», «участники», «ссылки», «фото», «видео», «аудио», «документы». Контент-анализ интерактивной стены и рубрик показал, что наиболее актуальными являются три темы: отчеты о торжественных богослужениях в храме, праздниках и паломнических поездках прихожан; анонсирование православных мероприятий в пределах города (прибытие мощей, праздничные богослужения); занятия детской воскресной школы.

Сетевое сообщество храма в честь Святых Целителей Космы и Дамиана Ассийских структурировано следующими рубриками: «информация», «обсуждение», «участники», «ссылки», «фото», «видео», «контакты». Контент-анализ интерактивной стены и рубрик показал, что самыми востребованными являются две темы: жизнь прихода (торжественные службы, паломнические поездки); крупные события православной жизни города (прибытие мощей, строительство нового храма, визит митрополита).

Сетевое сообщество Приход во имя Успения Пресвятой Богородицы (ВИЗ) структурировано по рубрикам: «информация», «участники», «ссылки», «фото», «видео», «документы», «контакты». Самые активные и коммуникативно насыщенные рубрики «фото», «видео», «ссылки». Контент-анализ интерактивной стены и рубрик показал, что чаще всего обсуждаются шесть тем: торжественные богослужения в храме; деятельность детского приходского центра «Успение»; мероприятия семейного клуба «Подсолнухи»; работа воскресной школы; жизнь прихода (паломнические поездки, дни рождения прихожан); мастер-классы благотворительного проекта рукодельной мастерской храма «От Сердца к Сердцу» (проект имеет собственное сообщество в социальной сети vk.com).

Сетевое сообщество храма во имя Святого Великомученика Георгия Победоносца структурировано по рубрикам: «информация», «расписание богослужений», «участники», «ссылки», «обсуждение», «фото», «видео», «документы», «мероприятия», «контакты». Контент-анализ интерактивной стены и рубрик показал, что самыми актуальными являются четыре темы: праздники и торжественные службы; участие прихожан в фестивале «Царские дни» и других городских православных событиях; благотворительные акции; православное воспитание и образование. 
Храмы спальных районов

\begin{tabular}{|c|c|c|c|c|c|c|c|}
\hline П.н. & Храм & Священник & Прихожане & $\begin{array}{l}\text { Группы } \\
\text { в vk.com }\end{array}$ & $\begin{array}{c}\text { Исповедь } \\
\text { в расписании } \\
\text { служб } \\
\end{array}$ & $\begin{array}{c}\text { Исповедь } \\
\text { как ритуал, } \\
\text { средство } \\
\end{array}$ & $\begin{array}{c}\text { Исповедь } \\
\text { как таинство, } \\
\text { тема } \\
\end{array}$ \\
\hline 1 & $\begin{array}{l}\text { Градо-Екатерин- } \\
\text { бургская } \\
\text { Симеоновская } \\
\text { церковь-школа }\end{array}$ & Нет & Нет & $\begin{array}{l}\text { https://vk. } \\
\text { com/sime } \\
\text { one_ekb }\end{array}$ & Нет расписания & Нет & Нет \\
\hline 2 & $\begin{array}{l}\text { В честь Святых } \\
\text { Целителей } \\
\text { Космы и } \\
\text { Дамиана } \\
\text { Асийских }\end{array}$ & Нет & Нет & $\begin{array}{l}\text { https://vk. } \\
\text { com/paris } \\
\text { hioners }\end{array}$ & Нет расписания & Нет & Нет \\
\hline 3 & $\begin{array}{l}\text { Приход во имя } \\
\text { Успения } \\
\text { Пресвятой } \\
\text { Богородицы } \\
\text { (ВИЗ) } \\
\end{array}$ & Нет & Нет & $\begin{array}{l}\text { https://vk. } \\
\text { com/sobor } \\
\text { _uspenie }\end{array}$ & Нет расписания & Нет & Нет \\
\hline 4 & $\begin{array}{l}\text { Во имя Святого } \\
\text { Великомученика } \\
\text { Георгия } \\
\text { Победоносца }\end{array}$ & Нет & $\begin{array}{l}\text { В сообществе } \\
\text { vk.сот помещен } \\
\text { список } \\
\text { прихожан, } \\
\text { ответственных за } \\
\text { различные } \\
\text { направления } \\
\text { работы храма со } \\
\text { ссылками на их } \\
\text { профили vk }\end{array}$ & $\begin{array}{l}\text { https://vk. } \\
\text { com/geor } \\
\text { gi_xram }\end{array}$ & $\begin{array}{l}\text { Имеется рубрика } \\
\text { «расписание } \\
\text { богослужений», } \\
\text { время исповеди } \\
\text { не указано }\end{array}$ & Нет & Нет \\
\hline 5 & $\begin{array}{l}\text { Во имя Успения } \\
\text { Пресвятой } \\
\text { Богородицы } \\
\text { (Эльмаш) }\end{array}$ & Нет & Нет & $\begin{array}{l}\text { https://vk. } \\
\text { com/uspen } \\
\text { ie.elmash }\end{array}$ & $\begin{array}{l}\text { Имеется рубрика } \\
\text { «расписание } \\
\text { богослужений», } \\
\text { время исповеди } \\
\text { не указано }\end{array}$ & Нет & Нет \\
\hline 6 & $\begin{array}{l}\text { Во имя } \\
\text { преподобного } \\
\text { Сергия } \\
\text { Радонежского и } \\
\text { преподобной } \\
\text { мученицы } \\
\text { Елисаветы }\end{array}$ & Нет & Нет & $\begin{array}{l}\text { https://vk. } \\
\text { com/club4 } \\
5369030\end{array}$ & $\begin{array}{l}\text { Имеется рубрика } \\
\text { «расписание } \\
\text { богослужений», } \\
\text { время исповеди } \\
\text { ежедневно } \\
\text { с 09:30 }\end{array}$ & $\begin{array}{l}\text { Пост о } \\
\text { правилах } \\
\text { подготов- } \\
\text { ки ребен- } \\
\text { ка к испо- } \\
\text { веди; под- } \\
\text { робный } \\
\text { рассказ о } \\
\text { подготов- } \\
\text { ке и про- } \\
\text { ведении } \\
\text { обряда и } \\
\text { об отли- } \\
\text { чиях меж- } \\
\text { ду взрос- } \\
\text { лыми и } \\
\text { детскими } \\
\text { испове- } \\
\text { дью и } \\
\text { причас- } \\
\text { тием }\end{array}$ & Нет \\
\hline 7 & $\begin{array}{l}\text { Храм Рождества } \\
\text { Христова } \\
\text { (Уралмаш) }\end{array}$ & Нет & Нет & $\begin{array}{l}\text { https://vk. } \\
\text { com/hram } \\
\text { rojdestvah } \\
\text { ristova }\end{array}$ & Нет расписания & Нет & Нет \\
\hline 8 & $\begin{array}{l}\text { Во имя Святой } \\
\text { Блаженной } \\
\text { Матроны } \\
\text { Московской }\end{array}$ & Нет & Нет & $\begin{array}{l}\text { https://vk. } \\
\text { com/mos } \\
\text { matrona }\end{array}$ & Нет расписания & Нет & Нет \\
\hline
\end{tabular}


E.A. Островская. Интернет-медиатизация исповеди в среде православных сетевых vk.com сообществ

Сетевое сообщество Храма Успения Пресвятой Богородицы (Эльмаш) содержит следующий набор рубрик: «информация», «свежие новости», «участники», «фото», «видео», «ссылки», «обсуждения», «мероприятия», «контакты». Наиболее активны рубрики «фото», «видео» и «обсуждения». Контент-анализ интерактивной стены и рубрик показал, что наиболее востребованными являются три темы: работа православного детского сада при храме, театрального кружка и детской воскресной школы; расписание служб и анонс торжественных служб и молебнов; записи проповедей настоятеля.

Сетевое сообщество храма во имя Преподобного Сергия Радонежского и преподобной мученицы Елисаветы структурировано рубриками: «информация», «новости», «аудиозаписи», «участники», «ссылки», «фото», «видео», «контакты». Контент-анализ интерактивной стены и рубрик показал, что самыми актуальными являются три темы: расписание служб; анонсы мероприятий собственного образовательного проекта «Елизаветинские Православные Семейные Классы»; фестиваль «Царские дни» и статьи о жизни императора Николая II и его семьи.
Сетевое сообщество храма во имя Рождества Христова (Уралмаш) структурировано по рубрикам: «информация», «деятельность прихода», «участники», «ссылки», «фото», «видео», «аудио», «документы», «контакты». Контент-анализ интерактивной стены и рубрик показал, что чаще всего встречаются три темы: организация православного воспитания и образования детей прихожан и самих прихожан храма (работа детского летнего лагеря, приходской школы, фотошколы для детей, слет православной молодежи, проект «Школа родителей», мероприятия проекта «Елизаветинские Православные семейные классы»); записи проповедей настоятеля; фестиваль «Царские Дни».

Сетевое vk.com сообщество Во имя Святой Блаженной Матроны Московской.

\section{Храмы окраинных районов - 3 vk.com сообщества (см. табл. 3)}

Сетевое сообщество Архиерейского подворья во имя святителя Саввы Сербского структурировано рубриками: «участники», «ссылки», «фото», «видео», «аудиозаписи», «обсуждения», «контакты». Контент-анализ интерактивной стены и рубрик показал, что чаще всего встречаются три темы: анонсы

Таблица 3

Храмы окраинных районов

\begin{tabular}{|c|c|c|c|c|c|c|c|}
\hline П.н. & Храм & Священник & Прихожане & $\begin{array}{l}\text { Группы } \\
\text { в vk.com }\end{array}$ & $\begin{array}{c}\text { Исповедь в расписании } \\
\text { служб }\end{array}$ & $\begin{array}{c}\text { Исповедь } \\
\text { как ритуал } \\
\text { средство }\end{array}$ & $\begin{array}{c}\text { Исповедь } \\
\text { как } \\
\text { таинство } \\
\text { тема } \\
\end{array}$ \\
\hline 1 & $\begin{array}{l}\text { Архиерей- } \\
\text { ское } \\
\text { подворье } \\
\text { во имя } \\
\text { святителя } \\
\text { Саввы } \\
\text { Сербского } \\
\end{array}$ & Нет & Нет & $\begin{array}{l}\text { https://vk.co } \\
\text { m/savva.orth } \\
\text { odoxy }\end{array}$ & Нет расписания & Нет & Нет \\
\hline 2 & $\begin{array}{l}\text { Святого } \\
\text { Равноапо- } \\
\text { стольного } \\
\text { князя } \\
\text { Владимира }\end{array}$ & Нет & Нет & $\begin{array}{l}\text { https://vk.co } \\
\text { m/vladimire } \\
\text { kbru }\end{array}$ & $\begin{array}{l}\text { Имеется рубрика } \\
\text { «Расписание } \\
\text { богослужений», время } \\
\text { исповеди ежедневно, } \\
\text { кроме вторника и } \\
\text { четверга, в 16:00 }\end{array}$ & Нет & Нет \\
\hline 3 & $\begin{array}{l}\text { Владимир- } \\
\text { ской иконы } \\
\text { Божией } \\
\text { Матери } \\
\text { на Семи } \\
\text { Ключах }\end{array}$ & Нет & Нет & $\begin{array}{l}\text { https://vk.co } \\
\text { m/vladprihod }\end{array}$ & $\begin{array}{l}\text { Имеется рубрика } \\
\text { «Расписание } \\
\text { богослужений», время } \\
\text { исповеди ежедневно, } \\
\text { кроме четверга, в 16:00 }\end{array}$ & Нет & Нет \\
\hline
\end{tabular}


церковных праздников; цитаты из святоотеческой литературы; отчеты о творческой активности прихожан.

Сетевое сообщество Храма Святого

Князя Владимира имеет следующие рубрики: «информация», «расписание богослужений», «участники», «ссылки», «фото», «видео», «аудио», «документы», «обсуждения», «контакты». Контент-анализ интерактивной стены и рубрик показал, что чаще всего встречаются три темы: волонтерская помощь дому престарелых «Достойная Старость»; распространение православных ценностей в среде российской молодежи; работа службы милосердия храма.

Сетевое сообщество храма Владимирской Иконы Божьей матери на Семи Ключах структурировано рубриками: «информация», «подписчики», «ссылки», «фото», «видео», «аудио», «мероприятия», «контакты». Контент-анализ интерактивной стены и рубрик показал, что наиболее актуальными являются три темы: анонсы мероприятий прихода (открытые лекции, беседы, расписание богослужений и молебнов); работа воскресной школы и детского поискового лагеря «Орленок»; помощь тяжело больным детям храма.

Подведем итог результатов наблюдения коммуникативной среды сетевого взаимодействия vk.com сообществ. По частотности сетевого взаимодействия ключевыми являются тематики интерактивных стен и рубрик «фото», «видео», «участники» и «контакты». Контент-анализ частотности тем коммуникации позволил выделить 3 ключевые темы: православное воспитание и образование (14 случаев из 22); жизнь прихода (службы и молебны, беседы, паломнические поездки) (8 случаев из 22); расписание служб (6 случаев из 22). К актуальным темам коммуникации на интерактивных стенах и в ведущих рубриках сообществ относятся: службы милосердия и благотворительные / социальные проекты; анонсы городских мероприятий православной тематики - в 5 случаях из 22; работа молодежных клубов; торжественные богослужения; записи проповедей / «Беседы с батюшкой» - в 4 случаях из 22; фестиваль «Царские дни», император Николай II и его семья; службы митрополита в храмах города, прибытие мощей - в 3 случаях из 22.

Исповедь как коммуникация относится к числу редко появляющихся тем. Отдельные единицы исповеди как коммуникации обнаружены в 9 сетевых храмовых сообществах vk.com. Проведенный анализ показывает, что из единиц исповеди в коммуникации обнаруживаются такие, как «время», «ритуал», «таинство» и «прихожане». Так, в vk.com сообществе Храма-Памятника на Крови (см. табл. 2, № 2) обнаружен только один пост, посвященный важности причастия для христианина. Он представляет собой цитату из речи патриарха Кирилла. На сайте Храма-Часовни святой великомученицы Екатерины (см. табл. 2, № 6) исповедь представлена в постах на интерактивной стене - всего четыре записи. Первая - краткий текстовой отчет и фотографии беседы прихожан со священником, в ходе которой обсуждались исповедь и причастие. Вторая - текстовая запись беседы с бывшим протестантским пастором, а ныне православным священником, который излагает свои мысли о важности и значении обряда исповеди в православии. Здесь исповедь предстает в двух единицах как ритуал и таинство. Две другие записи на интерактивной стене упоминают исповедь в контексте жития святого как таинство, придающее сил в духовной и мирской жизни. В сообществе храма «Большой Златоуст» в рубрике «обсуждения» есть тема «Вопросы батюшке», которая содержит вопросы по исповеди с ответами священника. Вопросы об исповеди связаны обычно с возникающими противоречиями между процедурными правилами проведения исповеди как ритуала и реальной жизненной ситуацией прихожанина. Чаще всего прихожане подчеркивают, что в силу своих жизненных обстоятельств не могут выполнить все церковные предписания или вынужденно нарушают какие-либо из них. В данном случае исповедь предстает единицами «тема» и «ритуал». В сообществе храма Успения Пресвятой Богородицы (на ВИЗе) в рубрике «видео» выложены записи бесед и проповедей священника, раскрывающих смысл и важность таинства исповеди. В сетевых сообществах храма во имя Преподобного Сергия Радонежского и 
Преподобной мученицы Елисаветы, Храма во имя Святого Великомученика Георгия Победоносца, Храма Часовни святой великомученицы Екатерины исповедь представлена единицей «прихожане». На интерактивной стене храма во имя Преподобного Сергия Радонежского и Преподобной мученицы Елисаветы есть видеозапись-инструкция, подробно рассказывающая о том, как подготовиться к обрядам исповеди и причастия ребенку. В сетевом взаимодействии группы храма Иоанно-Предтеченского собора беседы об исповеди, покаянии, причастии, заботе о ближнем - наиболее обсуждаемые темы прихрамового молодежного клуба. В данном случае исповедь коммуникативно представлена двумя своими единицами: «ритуал» и «таинство». В сетевых сообществах храма «Большой Златоуст», Храма во имя Святого Великомученика Георгия Победоносца, храма-часовни святой великомученицы Екатерины, храма в честь Святого Равноапостольного князя Владимира исповедь представлена единицей «время» - расписание богослужений.

Как показал анализ взаимодействия сетевых сообществ храмов в vk.com, структурная единица «цифровое пространство храмов» презентирует 22 vk.com сообщества, описанных подробно выше. Применительно к исповеди коммуникативная единица «время» оказалась мало актуализируемой - в большинстве сообществ время исповеди в расписаниях служб вообще не указано. Исповедь представлена единицей «время» в двух сетевых сообществах храмов центра (см. табл. 1, № 5, 6), в одном vk.com сообществе храма спального района (см. табл. 2, № 8), двух сообществах храмов окраинных районов (см. табл. 3, № 2, 3). Единица «священник» встречается два раза (см. табл. 1, № 8; табл. 2 , № 3).

В контексте нашего исследования структурных единиц исповеди особый интерес представляет рубрика «контакты», поскольку позволяет получить представление о том, кто создает группы храмовых сообществ vk.com. Создателями и администраторами таких групп vk.com чаще всего выступают прихожане. Однако в случаях сетевых сообществ крупных приходов ими часто являются сотрудники различных отделов Екатеринбургской епархии (см. табл. 2, № 13; табл. 3, № 3-4), реже - настоятели приходов (см. табл. 2, № 6, 10-11; табл. 3, № 6; табл. 4, № 3). В одном случае группу администрирует матушка прихода (см. табл. 2, № 7). Следует отметить, что в vk.com есть возможность отследить, кто администрирует контент, но остается открытым вопрос о модерировании и тематизации самого взаимодействия vk.com.

В сетевых vk.com сообществах коммуникативная единица исповедь как ритуал обнаружена в 5 случаях из 22: в четырех группах храмов центра и в одном храме спального района (см. табл. 1, № 2, 6, 8, 11; табл. 2, № 8). Интерактивное рассмотрение исповеди как таинства обнаружено в 3 случаях из 22: в храмах центрального и спального районов (см. табл. 1, № 6, 8; см. табл. 2, № 4). В каждом из трех случаев коммуникация единицы «таинство» раскрывается в беседах прихожан со священниками по темам духовной соотнесенности исповеди и причастия, доктринального смысла покаяния, ценностное содержание этого таинства.

Проведенное исследование позволяет констатировать, что в коммуникативном контексте взаимодействия храмовых vk.com coобществ превалирующими коммуникативными тематиками являются православное воспитание, жизнь прихода (службы и молебны, беседы, паломнические поездки), мероприятия православной жизни города, в число которых неизменно включены фестивали «Царские дни». Коммуникация «исповедь» является неактуальной по всем своим ключевым составляющим (она здесь относится к числу редко встречающихся тем). Такие единицы исповеди, как «время», «ритуал», «таинство» и «прихожане», обнаружены только в 9 храмовых сообществах. Однако ни в одном из них не обнаруживается наличие всех компонентов исповеди.

\section{ПРИМЕЧАНИЕ}

${ }^{1}$ Исследование выполнено при финансовой поддержке РФФИ в рамках научного проекта № 16-03-00-387. 


\section{СПИСОК ЛИТЕРАТУРЫ}

1. Колозариди, П. В. Интернет как проблемное поле социальных наук / П. В. Колозариди, М. О. Макушева // Мониторинг общественного мнения: экономические и социальные перемены. - 2018. - № 1. C. 1-11.-DOI: 10.14515/monitoring.2018.1.01.

2. Островская, Е. А. Структурированное наблюдение как метод изучения религиозного ландшафта / Е. А. Островская, Е. В. Алексеева // Мониторинг общественного мнения: экономические и социальные перемены. - 2018. - № 2. - С. 71-115.

3. Campbell, H. Introduction / H. Campbell, M. Lovheim // Information, Communication \& Society. - 2011. - Vol. 14, № 8. - P. 1083-1096.

4. Cantwell, Chr. D. Religion, Media, and the Digital Turn / Chr. D. Cantwell, R. Hussein // A Report for the Religion and the Public Sphere Program Social Science Research Council. December 2015. The Social Science Research Council. - Electronic text data. Mode of access: https://www.ssrc.org/publications/ view/religion-media-and-the-digital-turn (date of access: 18.09.2018). - Title from screen.

5. Denzin, N. K. Symbolic interactionism and ethnomethodology: a proposed synthesis / N. K. Denzin // American Sociological Review. - 1969. - Vol. 34 (6). P. 922-934.

6. Denzin, N. K. TheSAGE Handbook ofQualitative Research/N. K. Denzin, Y. S. Lincoln. $-3^{\text {rd }}$ ed. - Thousand Oaks, CA : Sage. $-2005 .-1210$ p.

7. Denzin, N. K. TheSAGE Handbook ofQualitative Research / N. K. Denzin, Y. S. Lincoln. $-4^{\text {th }}$ ed. - Thousand Oaks, CA : Sage. $-2011 .-784$ p.

8. Hjarvard, S. Three Forms of Mediatized Religion Changing the Public Face of Religion / S. Hjarvard ; Mia Lovheim (eds.) // Mediatization and Religion. Nordic Perspectives. - Goteborg : Nordicom, 2012. - P. 21-44.

\section{REFERENCES}

1. Kolozaridi P.V., Makusheva M.O. Internet kak problemnoe pole sotsialnykh nauk [The Internet as a Problematic Field of Social Sciences]. Monitoring obshchestvennogo mneniya: ekonomicheskie $i$ sotsialnye peremeny [The Monitoring of Public Opinion: Economic and Social Changes], 2018, no. 1, pp. 1-11. DOI: 10.14515/monitoring.2018.1.01.

2. Ostrovskaya E.A., Alekseeva E.V. Strukturirovannoe nablyudenie kak metod izucheniya religioznogo landshafta [Structured Observation as a Method of Studying Religious Landscape]. Monitoring obshchestvennogo mneniya: ekonomicheskie $i$ sotsialnye peremeny [The Monitoring of Public Opinion: Economic and Social Changes], 2018, no. 2, pp. 71-115.

3. Campbell H., Lovheim M. Introduction. Information, Communication \& Society, 2011, vol. 14, no. 8, pp. 1083-1096.

4. Cantwell Ch.D., Hussein R. Religion, Media, and the Digital Turn. A Report for the Religion and the Public Sphere Program Social Science Research Council, December 2015. The Social Science Research Council. URL: https://www.ssrc.org/publications/view/religionmedia-and-the-digital-turn/ (accessed 18 September 2018).

5. Denzin N.K. Symbolic interactionism and ethnomethodology: a proposed synthesis. American Sociological Review, 1969, vol. 34 (6), pp. 922-934.

6. Denzin N.K., Lincoln Y.S. The SAGE Handbook of Qualitative Research. $3^{\text {rd }}$ ed. Thousand Oaks, CA, Sage, 2005. 1210 p.

7. Denzin N.K., Lincoln Y.S. The SAGE Handbook of Qualitative Research. $4^{\text {th }}$ ed. Thousand Oaks, CA, Sage, 2011. 784 p.

8. Hjarvard S. Three Forms of Mediatized Religion Changing the Public Face of Religion. Mediatization and Religion. Nordic Perspectives. Goteborg, Nordicom, 2012, pp. 21-44.

\section{Information about the Author}

Elena A. Ostrovskaya, Doctor of Sciences (Sociology), Associate Professor, Professor of Department of Theory and History of Sociology, Saint Petersburg State University, Universitetskaya Emb., 7/9, 199034 Saint Petersburg, Russian Federation, e.ostrovskaya@spbu.ru.

\section{Информация об авторе}

Елена Александровна Островская, доктор социологических наук, доцент, профессор кафедры теории и истории социологии, Санкт-Петербургский государственный университет, Университетская наб., 7/9, 199034 г. Санкт-Петербург, Российская Федерация, e.ostrovskaya@spbu.ru. 